Jurnal Insan Farmasi Indonesia, 3(2) Desember 2020 (413-422)

Yovina Ika Adiaswati

p-ISSN 2621-3184 ; e-ISSN 2621-4032

doi: 10.36387/jifi.v3i2.578

\title{
OPTIMASI FORMULA PATCH KOSMETIK EKSTRAK METANOL DAUN PACAR AIR (Impatiens balsamina L.) DENGAN KOMBINASI MATRIKS HPMC DAN POLIETILEN GLIKOL 400 SECARA SIMPLEX LATTICE DESIGN
}

\author{
Yovina Ika Adiaswati*, Dian Puspitasari, Disa Andriani \\ Fakultas Farmasi, Stikes Nasional 664830, Indonesia \\ *: yovina.ika96@gmail.com
}

\begin{abstract}
ABSTRAK
Daun pacar air mengandung senyawa kumarin, flavonoid, kuinon, dan saponin yang telah diketahui mempunyai aktivitas antibakteri. Tujuan dari penelitian ini adalah untuk mengetahui proporsi optimum kombinasi HPMC dan Propilen Glikol 400 dan mengetahui aktivitas antibakteri patch ekstrak methanol daun pacar air. Ekstraksi menggunakan metode maserasi dengan metanol. Optimasi dilakukan dengan menggunakan simplex lattice design, diuji mutu fisik. Formula optimum selanjutnya di verifikasi dengan menggunakan uji T-test. Uji aktivitas antibakteri sediaan patch dilakukan dengan melihat besar zona hambat, data diameter daya hambat yang diperoleh diolah dengan statistik ANOVA. Hasil penelitian formula patch dengan kombinasi HPMC (11.25gram) dan PEG 400 (3.75gram). PEG 400 tidak dapat digunakan secara tunggal karena tidak dapat berbentuk padat. Hasil uji aktivitas sediaan patch ekstrak metanol daun pacar air terhadap bakteri Staphylococcus epidermidis menunjukan rata-rata diameter zona hambat yaitu sebesar $15.16 \pm 0.75 \mathrm{~mm}$. Hasil uji ANOVA one way diperoleh data $0.096>0.05$, menujukkan bahwa antara kontrol positif dengan sampel tidak berbeda signifikan. Kata kunci: Staphylococcus epidermidis, Optimasi HPMC dan PEG 400, Patch, Ekstrak Metanol Daun Pacar Air
\end{abstract}

\section{ABSTRACT}

Pacar air leaves contain coumarin compounds, flavonoids, quinones, and saponins which are known to have antibacterial activity. The purpose of this study was to determine the optimum proportion of the combination of HPMC and Propylene Glycol 400 and to determine the antibacterial activity of the methanol extract patch of pacar air leaves. Extraction using the maceration method with methanol. Optimization is done using the simplex lattice design, tested for physical quality. The optimum formula is then verified using the T-test. Antibacterial activity test of patch preparations was carried out by looking at the size of the inhibition zone, the inhibition diameter data obtained were processed with ANOVA statistics. The results of this research were the patch formula with a combination of HPMC (11.25 grams) and PEG 400 (3.75 grams). PEG 400 cannot be used singly because it cannot be solid. The results of the activity test of the methanol extract of the leaves of water henna against the Staphylococcus epidermidis bacteria showed that the average diameter of the inhibition zone was $15.16 \pm 0.75 \mathrm{~mm}$. The results of one way ANOVA test obtained data of 0.096>0.05, indicating that the positive control with the sample was not significantly different. 
Jurnal Insan Farmasi Indonesia, 3(2) Desember 2020 (413-422)

Yovina Ika Adiaswati

p-ISSN 2621-3184 ; e-ISSN 2621-4032

doi: $10.36387 /$ jifi.v3i2.578

Keywords: Staphylococcus epidermidis, Optimization of HPMC and PEG 400, Patch, Methanol Extract of Pacar Air Leaves

\section{PENDAHULUAN}

Penyakit kulit yang sering timbul dan mengganggu para remaja adalah jerawat atau acne vulgaris ${ }^{6}$ Menurut penelitiaan Fissy et $a l^{4}$ salah satu bakteri penyebab jerawat adalah Staphylococcus epidermidis. Untuk mengatasi jerawat telah banyak sediaan anti jerawat yang beredar di pasaran mengandung antibiotik sintetik seperti eritromisin dan klindamisin, namun tidak sedikit yang memberikan efek samping seperti iritasi, penggunaan jangka panjang dapat menyebabkan resistensi.

Beberapa tanaman herbal yang dapat ditemukan di Indonesia masih belum dimanfaatkan secara maksimal, salah satunya adalah tanaman pacar air (Impatiens balsamina L.). Senyawa utama dari ekstrak metanol pacar air yang telah diteliti memiliki aktivitas antibakteri terhadap bakteri penyebab jerawat adalah senyawa golongan poliketida (naftokuinon) dan flavonoid (quercetin dan kaempferol) ${ }^{7}$.

\section{METODE PENELITIAN}

\section{Alat dan Bahan}

Alat-alat yang digunakan dalam penelitian ini meliputi timbangan digital (Acis BC500), oven (Memmert), rotary evaporator (IKA HB 10 basic), blender (Cosmos), cawan, mortir dan stamfer, cawan petri (Pyrex), toples kaca, beckerglass (Pyrex), gelas ukur (Pyrex), jangka sorong, oven, software desaign expert, mikroskop, cawan petri, ayakan 65 mesh, pH meter (ATC).

Bahan - bahan yang digunakan dalam penelitian ini adalah daun pacar air yang diperoleh dari daerah Sukoharjo, HPMC (PT. Lawlim Zecha), Polietilen Glikol 400 (Subur Kimia Jaya), metil paraben, propilen glikol (Cipta Kima), aquadest, metanol (Cipta Kimia), alumunium foil.

\section{Pengolahan Sampel}

Pengolahan sampel dengan mengambil bagian daun yang tidak terlalu tua dan juga tidak terlalu muda diambil pada waktu pagi hari lalu dicuci menggunakan air mengalir 
Jurnal Insan Farmasi Indonesia, 3(2) Desember 2020 (413-422)

Yovina Ika Adiaswati

p-ISSN 2621-3184 ; e-ISSN 2621-4032

doi: $10.36387 /$ jifi.v3i2.578

menempel, dikering anginkan setelah

dilarutkan dalam PG (campuran 3).

kering dimasukan ke dalam oven Campuran 1 kemudian ditambahkan dengan suhu $50^{\circ} \mathrm{C}$ selama 24 jam. Sampel yang telah kering dihaluskan menggunakan blender kemudian disaring dengan ayakan 65 mesh.

\section{Ekstraksi}

Ekstrak metanol daun pacar air dibuat dengan cara maserasi. Sebanyak 500gram serbuk simplisia daun pacar air direndam menggunakan metanol sebanyak $5000 \mathrm{~mL}$ dengan sesekali dilakukan pengadukan, ditutup dengan alumunium foil dan dibiarkan selama 3 hari, sampel yang direndam tersebut disaring menggunakan kertas saring kemudian dievaporasi menggunakan rotary evaporator dengan suhu $40^{\circ} \mathrm{C}$, dan di atas penangas air sampai diperoleh ekstrak kental. Ekstrak ditimbang dan disimpan dalam wadah gelas tertutup ${ }^{8}$.

\section{Pembuatan Patch}

Ekstrak dilarutkan dengan etanol (campuran 1). Basis HPMC dikembangkan dengan aquadest yang tersisa (campuran 2). Pada wadah yang berbeda metil paraben 
Jurnal Insan Farmasi Indonesia, 3(2) Desember 2020 (413-422)

Yovina Ika Adiaswati

p-ISSN 2621-3184 ; e-ISSN 2621-4032

doi: $10.36387 /$ jifi.v3i2.578

Tabel 1. Formula Patch Ekstrak Metanol Daun Pacar Air

\begin{tabular}{lccccccccc}
\hline \multicolumn{1}{c}{ Bahan } & \multicolumn{1}{c}{ Formula (\%) } \\
\cline { 2 - 8 } & RI & R2 & R3 & R4 & R5 & R6 & R7 & R8 & Fungsi \\
\hline Eks. Pacar air & 15 & 15 & 15 & 15 & 15 & 15 & 15 & 15 & Zat aktif \\
HPMC & 0 & 15 & 7,5 & 0 & 7,5 & 11,25 & 3,75 & 15 & Polimer \\
Polietilen Glikol 400 & 15 & 0 & 7,5 & 15 & 7,5 & 3,75 & 11,25 & 0 & Polimer \\
Metil Paraben & 0,3 & 0,3 & 0,3 & 0,3 & 0,3 & 0,3 & 0,3 & 0,3 & Pengawet \\
Propilenglikol & 10 & 10 & 10 & 10 & 10 & 10 & 10 & 10 & Plasticizer \\
Etanol & 40 & 40 & 40 & 40 & 40 & 40 & 40 & 40 & Pelarut \\
Aquadest ad & 100 & 100 & 100 & 100 & 100 & 100 & 100 & 100 & Pelarut \\
\hline
\end{tabular}

\section{Ketebalan}

Patch yang dihasilkan diukur ketebalannya dengan menggunakan alat jangka sorong. pengukuran dilakukan pada 5 tempat berbeda, ketebalan patch yang baik dilihat dari nilai standar deviasinya ${ }^{12}$.

\section{Persentase kandungan air}

Untuk memeriksa persentase kandungan air dari patch, berat patch ditimbang sebagai berat awal, kemudian ditempatkan dalam desikator yang berisi mengandung silica selama 24 jam. Setelah 24 jam, patch ini ditimbang kembali dan persentase kehilangan air dapat dihitung $^{12}$.

\section{Presentasi Pemanjangan}

Persen pemanjangan adalah perubahan panjang maksimum yang dapat dialami bahan pada saat mengalami peregangan atau ditarik sampai sebelum bahan itu robek ${ }^{16}$.

\section{Folding endurance}

Uji ketahanan suatu patch dilakukan dengan cara dilipat berulang kali di tempat yang sama sampai pecah. Banyaknya lipatan yang dapat dilakukan dianggap sebagai nilai ketahanan, nilai ketahanan lipat patch yang baik ialah lebih dari 200 kali lipatan $(>200)^{17}$.

\section{Loss on drying}

Patch ditimbang satu persatu kemudian dimasukkan ke dalam moisture balance pada suhu $105^{\circ} \mathrm{C}$ hingga alat menunjukkan angka susut pengeringan, nilai loss on drying yang baik $<10 \%{ }^{10}$. 
Jurnal Insan Farmasi Indonesia, 3(2) Desember 2020 (413-422)

Yovina Ika Adiaswati

p-ISSN 2621-3184 ; e-ISSN 2621-4032

doi: $10.36387 /$ jifi.v3i2.578

\section{Uji pH}

Uji $\mathrm{pH}$ permukaan dilakukan dengan menggunakan $\mathrm{pH}$ universal dengan rentang $\mathrm{pH}$ yang dapat ditoleransi untuk tidak mengiritasi kulit yaitu 4,5-6, $5^{13}$.

\section{Penentuan formula optimum}

Formula optimal ditentukan dengan melihat hasil uji sifat fisik. Hasil uji dari masing-masing formula kemudian diolah menggunakan metode simplex lattice design dengan memperhatikan nilai desirability yang mendekati 1,0.

\section{Verifikasi formula optimal}

Verifikasi formula optimum dengan menggunakan uji T-test.

\section{Uji Efek Antijerawat Patch}

\section{Formula Simplex Lattice Design}

Uji aktivitas antibakteri dengan metode difusi diletakkan sampel, kontrol negatif dan kontrol positif. Kontrol negatif (blangko) yang digunakan adalah sediaan patch yang tidak mengandung ekstrak metanol pacar air dan sebagai kontrol positif digunakan patch oxy dan sampel patch ekstrak metanol daun pacar air dipotong dengan menggunakan cork borer dengan diameter sebesar $0.8 \mathrm{~cm}$, kemudian diinkubasi pada suhu $37^{\circ} \mathrm{C}$ selama 24 jam. Diameter Daerah Hambat (DDH) yang terbentuk disekitar patch dengan menggunakan jangka sorong. Uji dilakukan dengan tiga kali pengulangan ${ }^{9}$.

\section{Hasil dan Pembahasan}

Penyarian dilakukan dengan menggunakan metode maserasi. Metode maserasi cocok untuk bahan dengan kandungan zat aktif yang tidak tahan panas, ekstrak yang dihasilkan sebanyak 51 gram dengan prosentase rendemen sebesar $10.2 \%$.

Upaya mendapatkan formula optimum dilakukan dengan cara optimasi dengan metode simplex lattice design respon yang diamati antara lain :

Uji organoleptik dilakukan untuk melihat tampilan fisik sediaan dengan cara melakukan pengamatan warna, bau, dan tekstur dari sediaan yang telah dibuat (Djajadisastra et al., 2009). Hasil yang diperoleh pada R1 dan R4 berwarna coklat dengan bentuk cair kental dan berbau aromatis ekstrak sedangkan R2, R3, R5, R6, R7, R8 berwarna coklat 
Jurnal Insan Farmasi Indonesia, 3(2) Desember 2020 (413-422)

Yovina Ika Adiaswati

p-ISSN 2621-3184 ; e-ISSN 2621-4032

doi: 10.36387/jifi.v3i2.578

berbentu padat dan beraroma $\mathrm{Y}=17.20975(\mathrm{~A})+0.184755(\mathrm{~B})+$ aromatis ekstrak.

38.10510 (AB) - 80.17333 (A-B)

Uji keseragaman bobot, seseragaman Ketebalan memiliki peran dalam sifat bobot dikatakan baik apabila memiliki nilai $\mathrm{CV}<5 \%$. Hasil Dari hasil respon bobot matriks patch, diperoleh hasil uji terhadap keseragaman bobot berdasarkan pendekatan simplex lattice

design didapatkan persamaan dan contour plot sebagai berikut:

$\mathrm{Y}=5.0715(\mathrm{~A})-2.1981(\mathrm{~B})+1.2610$ $(\mathrm{AB})-9.4013(\mathrm{~A}-\mathrm{B})+64.4120(\mathrm{~A}-$

B) $)^{2}$ Dimana $\mathrm{Y}$ adalah keseragaman bobot, A adalah HPMC dan B PEG 400 , AB perbandingan antara HPMC dan PEG 400.

Uji kadar air bertujuan untuk mengetahui besar kandungan air dalam sediaan patch yang dapat menyebabkan kontaminasi mikroorganisme sehingga stabilitas sediaan akan berkurang. Rentang kadar air yang dipersyaratkan yaitu 110\% (Kumar et al, 2014). diperoleh hasil uji terhadap kadar air berdasarkan pendekatan simplex lattice design didapatkan persamaan dan contour plot sebagai berikut: fisik patch, patch yang tipis akan lebih mudah diterima dalam pemakaiannya $^{11}$. Ketebalan patch dapat dianalisis dari nilai standar devisiasinya. berdasarkan pendekatan simplex lattice design didapatkan persamaan sebagai berikut :

$\mathrm{Y}=0.0540(\mathrm{~A})+0.000039(\mathrm{~B})+$ 0.0887 (AB) - 0.1440 (A-B)

Folding endurance, berdasarkan penelitian sebelumya jumlah ketahanan lipat yang memenuhi standar apabila ketahanan lipat lebih dari 200 kali lipatan ${ }^{14}$. Kombinasi keduanya digambarkan melalui persamaan dan contour plot dibawah ini :

$\mathrm{Y}=14.4248(\mathrm{~A})-2.4640(\mathrm{~B})+$ 1147.6078 (AB)

Daya serap kelembaban (loss on drying) merupakan salah satu parameter respon untuk menentukan kemampuan sebuah patch dalam menyerap lembab. Semakin kecil nilai persentase daya serap kelembaban maka akan menghasilkan patch yang lebih relatif stabil dan 
Jurnal Insan Farmasi Indonesia, 3(2) Desember 2020 (413-422)

Yovina Ika Adiaswati

p-ISSN 2621-3184 ; e-ISSN 2621-4032

doi: $10.36387 /$ jifi.v3i2.578

terlindungi dari kontaminasi

dari desirability tersebut semakin

mikroba $^{2}$. Diperoleh persamaan dan

contour plot dibawah ini :

$\mathrm{Y}=12.5250(\mathrm{~A})-6.2803(\mathrm{~B})+$

$5.8700(\mathrm{AB})$

Uji $\mathrm{pH}$ sediaan dilakukan dengan menggunakan indikator universal.

Syarat $\mathrm{pH}$ kulit adalah 4,5-6,5 sehingga tidak mengiritasi pada saat penggunaannya $^{13}$. Diperoleh persamaan dan contour plot sebagai berikut:

$\mathrm{Y}=6.0588(\mathrm{~A})+0.0588+13.1764$

$(\mathrm{AB})-16.0000(\mathrm{~A}-\mathrm{B})$

Persentase pemanjangan dapat didefinisikan sebagai persentase perubahan panjang film pada saat film ditarik sampai putus ${ }^{15}$. Presentasi pemanjangan dapat digambarkan pada persamaan dibawah ini :

$\mathrm{Y}=5.9764(\mathrm{~A})+0.3253(\mathrm{~B})+$ $69.6376(\mathrm{~A})(\mathrm{B})$

Penentuan formula optimum dilakukan dengan mengolah data respon yang memenuhi persyaratan dengan menggunakan software Design Expert. Berdasarkan analisis simplex lattice design nilai desirability yang paling tinggi yaitu 0.812 . Semakin mendekati 1,000 nilai baik. Berdasarkan titik tersebut maka diperoleh komposisi optimum sediaan patch ekstrak metanol daun pacar air HPMC 11.25 gram dan PEG 4003.75 gram.

Verifikasi formula optimal menggunakan analisis statistik yang digunakan one sample T-test dengan taraf kepercayaan 95\% digunakan untuk menguji signifikasi beda ratarata antara nilai hasil percobaan yang dilakukan dengan nilai teoritis hasil prediksi dari simplex lattice design. Diperoleh hasil Keseragaman bobot 0.389, folding endurance 0.077, persentase pemanjangan 0.069, ketebalan 0.070, kadar air 0.075, pH 0.027, loss on drying 0.089 Hasil analisis menunjukan bahwa nilai signifikasi uji keseragaman bobot, ketebalan, kadar air, folding endurance, loss on drying, presntasi pemanjangan nilai prediksi $>0.05$ menandakan data valid. Data tidak valid terdapat pada uji $\mathrm{pH}$ yang memiliki nilai signifikasi $<0.05$. Pengujian patch antibakteri terhadap bakteri Staphylococcus epidermidis menunjukan adanya hambatan pada 
Jurnal Insan Farmasi Indonesia, 3(2) Desember 2020 (413-422)

Yovina Ika Adiaswati

p-ISSN 2621-3184 ; e-ISSN 2621-4032

doi: $10.36387 /$ jifi.v3i2.578

bakteri ditunjukkan adanya zona jernih disekitar patch. Hasil diameter hambat pengujian patch ekstrak metanol daun pacar air diperoleh hasil rata rata daya hambat $\pm \mathrm{SD}$ $15.16 \pm 0.75$, Kontrol positif (patch oxy) 18.56 \pm 2.61 , Kontrol negatif (patch tidak menggandung ekstrak) $0 \pm 0$. Dihitung statistik yang digunakan yaitu one way ANOVA untuk sediaan patch ekstrak metanol daun pacar air. Perhitungan ShapiroWilk kontrol positif diperoleh data $0.831>0.05$ menunjukkan bahwa datanya normal sedangkan sampel patch ekstrak daun metanol daun pacar air diperoleh data $0.927>0.05$ menunjukan datanya normal, dapat dilanjutkan dengan uji ANOVA diperoleh hasil $0.00<0.05$ menunjukkan perbedaan pada sampel dengan kontrol.

\section{KESIMPULAN}

1. Formula patch ekstrak metanol daun pacar air yang optimum ditinjau dari parameter uji sifat fisik diperoleh dengan komposisi HPMC sebesar 11.25gram dan PEG 4003.75 gram.

2. Sediaan patch ekstrak metanol daun pacar air memiliki aktivitas antibakteri terhadap Staphylococcus epidermidis yang dihitung diameter hambatnya, dengan rata-rata luas zona hambat $15.16 \pm 0.75 \mathrm{~mm}$.

\section{UCAPAN TERIMAKASIH}

Diucapkan terimakasih kepada semua pihak yang telah berkontribusi dalam penelitian ini, sehingga penelitian ini dapat selesai dan bejalan dengan baik.

\section{DAFTAR PUSTAKA}

1. Adfa, M. Senyawa Antibakteri dari Daun Pacar Air (Impatiens balsamina L.). Jurnal Gradien, 4 (1), 318-322 (2008).

2. Ammar. H.O. Polymeric Matriks Sistem For Prolomged Delivery Of Tramadol Hydrochloride Part 1: Physichocemical Evaluation. AAPS Pharm Scitech, 10, 7-19 (2009).

3. Djajadisastra, J., Mun'im, A. and NP D, Formulasi Gel Topikal Dari Ekstrak Nerii Folium Dalam Sediaan Anti Jerawat. Jurnal Farmasi Indonesia, 4 (4) (2009).

4. Fissy, O.N., Sarim, R. dan Pratiwi, L. Efektivitas Gel Anti Jerawat Ekstrak Etanol Rimpang Jahe Merah (Zingiber officinale Rosc. Var. Rubrum) terhadap Propionibacterium acnes dan Staphylococcus epidermidis. Jurnal Ilmu Kefarmasian Indonesia 12 (2), 194-201 (2014). 
5. Kumar, S.V., Tarun, P. \& Kumar, T.A. Transdermal Drug Delivery System For Nonsteroidal Anti Anflammatory Drugs: A Review. Indo American Journal of Pharmaceutical Research, 3(4), 3588-3605 (2013).

6. Knutsen, Larson Siri. Annelise, L. Dawson, Cory A. Dunnick dan Robert, P, Dellavalle, Acne Vulgaris: Pathogenesis, Treatment, and Needs Assessment. Dermatol Clin, 30, 99-106 (2012).

7. Lim, Y.H. Kim, I.H, Seo, J.J. In vitro Activity of Kaempferol Isolated from the Impatiens balsamina alone and in Combination with Erythromycin or Clindamycin against P. acnes. The Journal of Microbiology, 45(5) (2007).

8. Malonda, Tasya., C, Paulina, V. Y, Yamlean, Gayatri, Citraningtyas. Formulasi Sediaan Sampo Antiketombe Ekstrak Daun Pacar Air (Impatiens Balsamina L.) Dan Uji Aktivitasnya Terhadap Jamur Candida Albicans Atcc 10231 Secara In Vitro. Pharmacon Jurnal Ilmiah Farmasi, UNSRAT, Vol. 6 No. 4 (2017).

9. Ningsih, P.A., Nurmiati, Agustien A. Uji Aktivitas Antibakteri Ekstrak Kental Tanaman Pisang Kepok Kuning (Musa paradisiaca Linn.) terhadap Staphylococcus aureus dan Escherichia coli. Jurnal Biologi Universitas Andalas, 2 (3), 24-27 (2013).

10. Patel, D., Setty, C. Mistry, G. Patel, S. Patel T. Mistry P. Rana A. Patel P. Mishra R.
Development And Evaluation Of Ethyl Cellulose Based Transdermal Films Of Furosemide For Improved In Vitro Skin Permeation. AAPS Pharm Sci Tech, 10(2), 437-442 (2009).

11. Prabhakara, P., Koland, M. Vijaynaraya K. Haarris NM. Shankar G. Mohd G A. Narayana C.R. Satyanarayana D. preparationand evaluation of transdermal patches of papaverin hydrochloride, J.Res.Pharm, 1,259-266 (2010).

12. Rahim, F., Deviarny, C. Yenti R, Ramadani P. Formulasi Sediaan Patch Transdermal Dari Rimpang Rumput Teki (Cyperus Rotundus L.) Untuk Pengobatan Nyeri Sendi Pada Tikus Putih Jantan. Scientia, 6 (1), 1- 6 (2016).

13. Rajab, N.A., dan M.S. Jawad. Formulation and in vitro evaluation of piroxicam microsponge as a tablet. International Journal of Pharmacy and Pharmaceutical Sciences, 8, 104-114 (2016).

14. Rajesh, S., Sujith, S. Permeation Of Flurbiprofen Polymeric Film Through Human Cadaver Skin. International Journal of Pharm Tech Research, Vol.5, No.1 (2013).

15. Rifqiani, Anantia., Rise, Desnita. Sri Luliana. Pengaruh Penggunaan Peg 400 Dan Gliserol Sebagai Plasticizer Terhadap Sifat Fisik Sediaan Patch Ekstrak Etanol Herba Pegagan (Centella asiatica (L) Urban). Jurnal Farmasi Kalbar, Vol 4 (2019). 
Jurnal Insan Farmasi Indonesia, 3(2) Desember 2020 (413-422)

Yovina Ika Adiaswati

p-ISSN 2621-3184 ; e-ISSN 2621-4032

doi: 10.36387/jifi.v3i2.578

16. Sahoo, Kumar Biraj., dan Amlya, Kenta Mishra. Formulation and Evaluation of Transdermal Patches of Diclofenac. Departement of Pharmaceutics, Collage of Pharmaceutical Science Marine Drive Road Puri, Odisha, India (2013).
17. Rani, S., Kamal, S. Navneet S. and Pooja M. Transdermal Patches a Successful Tool in Transdermal Drug Delivery System: An Overview. Pelagia Research Library, 2(5), 17-29 (2011) 